\title{
Pengaruh Video Praktikum Dengan Modul Elektronik Terhadap Keterampilan Proses Pada Materi Stoikiometri Siswa Kelas X SMAN 2 Tidore Kepulauan
}

\section{The Influence of Practicum Video with Electronic Module Toward Process Skills for Stoichiometry Materials of the Grade $X$ of SMAN 2 Tidore Islands}

\author{
Nur A. Limatahu*; Nurul Aulia Rahman*; St. Hayatun Nur Abu; Indra Cipta \\ Program Studi Pendidikan Kimia, Jurusan Pendidikan MIPA, FKIP, Universitas Khairun, Ternate- \\ Indonesia \\ “Korespondensi: ayahayatunnur@yahoo.co.id; rahman_nurulaulia@yahoo.com
}

\begin{abstract}
Abstrak: Penilitian ini bertujuan untuk mengetahui pengaruh video praktikum dengan modul elektronik terhadap keterampilan proses dan besar peningkatan keterampilan proses pada materi stokiometri siswa kelas X SMAN 2 Tidore Kepulauan.Jenis penelitian yang digunakan adalah penelitian eksperimen. Desain penelitian adalah OneGroup Pretest-Postest Design. Populasi penelitian adalah siswa kelas X SMAN 2 Tidore Kepulauan. Sampel penelitian adalah kelas $\mathrm{X}_{1}$ yang dipilih secara random. Teknik analisis data melalui analisis statistik deskriptif dan analisis statistik inferensial menggunakan SPSS 16 . Hasil uji hipotesis diperoleh sig< $<$,o5 dan $\mathrm{thitung}>\mathrm{t}$ tabel maka penggunaan video praktikum dan modul elektronik berpengaruh terhadap keterampilan proses siswa. Nilai Gain adalah 85\% menunjukkan interpretasi tinggi terhadap peningkatan keterampilan proses siswa.
\end{abstract}

Kata kunci: keterampilan proses, modul elektronik, video praktikum

Abstract: This study aimed to determine the effect of practicum video with electronics module toward process skills and how far the influence of stoichiometry materials of the grade X of SMA Negeri 2 Tidore Islands. This study used experiment research. The study design was experiment with One Group Pretest-Postest Design. The population was the grade $X$ students of SMAN 2 Tidore Islands. The sample was class $X_{1}$ chosen randomly. Data analysis technique was through statistical descriptive analysis and inferential statistical analysis which used SPSS 16. The results of hypothesis testing showed that sig $<0,05$ and $t$ count $>t$ table then the use of practicum video and electronic modules influence the process skills of students. Gain value is $85 \%$ indicating a high interpretations to the improvement process skills of students.

Keywords: process skills, electronics modul, practicum video

\section{PENDAHULUAN}

Pendidikan menurut Trianto (2007) merupakan proses persiapan peserta didik atau siswa untuk menyelesaikan permasalahan dalam pembelajaran, baik yang menyangkut pengetahuan maupun ketrampilan.

Keterampilan merupakan kemampuan untuk menggunakan pikiran, nalar dan perbuatan secara efisien dan efektif untuk mencapai hasil tertentu. Siswa dapat meningkatkan keterampilan proses apabila diberi kesempatan untuk terlibat langsung dalam kegiatan ilmiah, misalnya melaksanakan praktikum di laboratorium. Kegiatan praktikum merupakan salah satu unsur dan upaya yang tidak dapat dipisahkan dari pembelajaran kimia di sekolah.

Namun, pelaksanaan praktikum di sekolah mengalami kendala karena kurang lengkapnya sarana dan prasarana penunjang laboratorium, tidak adanya panduan praktikum serta akses internet yang tidak memadai. Untuk mengatasi keterbatasan dalam pelaksanaan praktikum, dibutuhkan suatu media dan modul praktikum sehingga siswa mendapatkan pengalaman belajarnya. Kegiatan praktikum di laboratorium sebenarnya dapat dilakukan bersamaan dengan

pembelajaran konsep. Kurangnya kegiatan praktikum mengakibatkan keterampilan laboratorium siswa cenderung rendah. Pengalaman belajar yang diberikan guru lebih ditekankan pada kegiatan ceramah dan latihan soal, sehingga hanya aspek kognitif saja yang dinilai. Padahal aspek afektif dan psikomotor penting untuk penilaian siswa selama proses pembelajaran (Baeti dkk., 2014). Keterbatasan sarana dan prasarana penunjang praktikum dapat diatasi dengan penggunaan video praktikum serta modul 
elektronik yang dapat membantu guru dalam membimbing siswa untuk memahami materi pelajaran.

Modul elektronik merupakan bahan ajar yang menggunakan piranti elektronik berupa teks, gambar maupun suara dengan tujuan untuk menunjukkan kepada siswa keterkaitan antara fakta, konsep, prosedur dan prinsip yang terkandung dalam materi pembelajaran.

Modul elektronik dapat diimplementasikan sebagai sumber belajar mandiri yang dapat membantu siswa dalam meningkatkan kompetensi atau pemahaman secara kognitif yang dimilikinya. Modul elektronik mempermudah siswa dalam mempelajari suatu materi karena mudah dibawa dimana dan kapan saja.

Penggunaan modul elektronik selain dapat mengatasi keterbatasan pelaksanaan praktikum, membantu guru, juga dapat meningkatkan keterampilan proses siswa. Dalam kegiatan pembelajaran dengan media elektonik, keterampilan proses siswa akan lebih meningkat karena kegiatan pembelajaran yang dilakukan melibatkan lebih banyak panca indera, selain itu siswa dapat berperan aktif, melatih keberanian berkomunikasi dan berusaha memperoleh pengetahuanya sendiri untuk memecahkan masalah yang dihadapi, sehingga apa yang mereka pelajari dapat bertahan lebih lama. Penelitian jenis ini telah dilakukan oleh peneliti sebelumnya, diantaranya oleh Erniwati dkk. (2014) dimana media praktikum berbasis video dalam pembelajaran dapat meningkatkan hasil pembelajaran. Oktiami dkk. (2014) menunjukkan pengaruh penggunaan multimedia interaktif pada praktikum titrasi asam basa, terlihat pada kegiatan praktikum lebih terarah karena siswa dapat bekerja secara sistematis sesuai panduan yang ada di dalam media. Waktu yang digunakan untuk praktikum juga lebih efektif. Pengembangan media pembelajaran video yang dilakukan oleh Agustina dan Novita (2012) menunjukkan bahwa media pembelajaran video layak digunakan sebagai media pembelajaran pada larutan asam basa SMA. Wijayanto \& Zuhri (2014) juga telah mengembangkan E-Modul untuk meningkatkan kemampuan pemecahan masalah.

Penelitian ini dilakukan dengan tujuan untuk mengetahui pengaruh video praktikum dan modul elektronik terhadap keterampilan proses dan besar peningkatan keterampilan proses siswa pada materi stoikiometri kelas X SMAN 2 Tidore Kepulauan.

\section{METODE}

Penelitan ini dilakukan di SMAN 2 Tidore Kepulauan pada siswa kelas $\mathrm{X}$ tahun ajaran 2016/2017. Jenis penelitian ini adalah penelitian eksperimen. Desain penelitian adalah One Group Pretest-Postest Design (Sugiyono, 2008). Penentuan sampel secara random. Sampel dalam penelitian ini yaitu siswa kelas $\mathrm{X}_{1}$ yang berjumlah 19 siswa. Variabel dalam penelitian ini adalah keterampilan proses dan video praktikum dengan modul elektronik.

Pengumpulan data dilakukan dengan teknik tes untuk mendapatkan nilai keterampilan proses siswa pada materi stoikiometri. Tes yang digunakan dalam penelitian ini yaitu tes tertulis berupa soal essay sebanyak 10 butir soal. Soal tersebut merupakan soal yang valid karena telah dilakukan validasi isi.

Data hasil penelitian ini berupa data hasil keterampilan proses siswa. Pengelolaan data hasil penelitian menggunakan dua teknik statistik, yaitu statistik deskriptif dan inferensial dengan menggunakan SPSS 16,0 for windows $(\alpha=0,05)$. Analisis statistik inferensial digunakan untuk menguji kebenaran hipotesis yang diujikan. Uji hipotesis dengan Paired Sample $T$ Test (Priyatno, 2009).

Besar peningkatan keterampilan berpikir sebelum dan sesudah perlakuan diketahui dengan menggunakan skor gain. Perhitungan ini berfungsi untuk mengetahui besar peningkatan keterampilan proses siswa. Perhitungan menggunakan skor gain dengan menggunakan persamaan:

$\frac{\text { hasil postes-hasil pretes }}{\text { hasil postes }} \times 100 \%$

Kriteria untuk tingkat perolehan skor gain adalah sebagai berikut:

a. Apabila skor gain $\geq 0,70$ interpresentasi tinggi

b. Apabila skor gain 0,30-0,70 interpresentasi sedang

c. Apabila skor gain $\leq 0,30$ interpresentasi rendah.

\section{HASIL DAN PEMBAHASAN}


Analisis statistik deskriptif memberikan gambaran terhadap keterampilan proses siswa yang diukur menggunakan instrument tes dengan pemberian pretest dan posttest pada kelas $\mathrm{X}_{1}$. Data hasil analisis deskriptif terhadap keterampilan proses siswa Kelas X SMA Tidore kepulauan dengan video praktikum dan modul elektronik pada materi stoikiometri selengkapnya ditunjukkan pada Tabel 1.

Tabel 1. Analisis deskriptif keterampilan proses siswa.

\begin{tabular}{lcc}
\hline \multicolumn{1}{c}{ Data } & Pretes & Postes \\
\hline Jumlah Siswa & 19 & 19 \\
Nilai Minimum & 0,00 & 0,00 \\
Nilai Maksimal & 26,50 & 77,80 \\
Mean & 8,06 & 53,74 \\
Standar Deviasi & 6,14 & 20,17 \\
\hline
\end{tabular}

Keterampilan proses siswa setelah dilakukan pembelajaran dengan video praktikum dan modul elektronik mengalami peningkatan. Rata-rata peningkatan skor keterampilan proses siswa dapat dilihat pada Tabel 2.

Tabel 2. Peningkatan Keterampilan Proses Siswa

\begin{tabular}{lc}
\multicolumn{1}{c}{ Kelas $\mathrm{X}_{1}$. } \\
\hline \multicolumn{1}{c}{ Data } & Nilai \\
\hline Pretes & 8.06 \\
Postes & 53.74 \\
Peningkatan rata-rata & 45.68 \\
Keterampilan Proses Siswa & \\
NilaiGain (\%) & 85 \\
\hline
\end{tabular}

Nilai gain $85 \%$ menunjukkan interpretasi tinggi terhadap peningkatan keterampilan proses siswa setelah penggunaan video praktikum dengan modul elektronik pada materi stokiometri.

Setelah dilakukan analisis statistik deskriptif, selanjutnya dilakukan uji Normalitas terhadap data pretes dan postes. Pengujian normalitas dengan SPSS 16 for windows dengan analisis One-SampleKolmogorov-Smirnov Test data terdistribusi normal, (p) $>a=0,05$ dapat dilihat pada Tabel 3 .

Tabel 3. Hasil Kolmogorov-Smirnov Test terhadap Keterampilan proses siswa Kelas $\mathrm{X}_{1}$

\begin{tabular}{ccc}
\hline & \multicolumn{2}{c}{ Kelas eksperimen } \\
\cline { 2 - 3 } & Pretes & Postes \\
\hline Signifikansi (p) & 0,482 & 0,052 \\
\hline
\end{tabular}

Data selanjutnya diuji hipotesis menggunakan SPSS 16 dengan analisis Paired Sampel $T$ Test, selengkapnya dapat dilihat pada Tabel 4 .

Tabel 4. Uji Hipotesis

\begin{tabular}{lc}
\hline \multicolumn{1}{c}{ Data } & Hasil Analisis \\
\hline t hitung & 9,354 \\
t tabel & 1,734 \\
Df & 18 \\
Sig & 0,000 \\
\hline
\end{tabular}

Berdasarkan uji hipotesis diperoleh sig< o,05 dan $t$ hitung $>t$ tabel maka penggunaan video praktikum dan modul elektronik berpengaruh terhadap peningkatan keterampilan proses siswa.

Hasil penelitian tersebut menunjukkan bahwa pembelajaran dengan media praktikum dan modul elektronik mampu meningkatkan keterampilan proses siswa. Setelah mengamati video praktikum tersebut siswa kemudian mengumpulkan data atau informasi, menganalisisnya, menemukan jawaban dari pertanyaan yang telah tercantum pada modul elektronik, selanjutnya memaparkan di kelas hasil dan kesimpulan yang mereka dapatkan. Dengan adanya modul elektronik dan video praktikum, dapat menjadi sumber belajar mandiri bagi siswa. Hal ini sesuai dengan teori yang dikemukakan oleh Kustiani dkk (dalam Erniwati dkk., 2014) bahwa dengan menggunakan video, siswa lebih mudah belajar tidak hanya di sekolah namun juga bisa di rumah.

Video praktikum yang dilengkapi modul elektronik dapat digunakan oleh siswa untuk mengulang materi yang telah diberikan, tidak hanya melalui pendengaran, materi yang diberikan dapat mereka lihat secara langsung dari video tersebut. Sehingga, penguasaan siswa terhadap materi pembelajaran lebih baik. Hal tersebut secara langsung berdampak pada peningkatan hasil belajar dan keterampilan proses. Siswa juga memberikan respon positif terhadap modul praktikum kimia SMA yang dikembangkan oleh Rosmalinda dkk. (2013). Penggunaan modul ektronik juga sangat membantu siswa untuk memahami materi atau praktikum. Selain itu, penggunaan video praktikum dengan modul elektronik juga sangat membantu guru dalam mengatasi keterbatasan pelaksanaan praktikum. 
Hal ini didukung oleh Zulvianda dkk. (2016) yang mengemukakan bahwa E-modul yang dikembangkan mendapat tanggapan positif dari guru dan siswa.

\section{KESIMPULAN}

Berdasarkan hasil penelitian, dapat disimpulkan bahwa: (1) terdapat pengaruh video praktikum dengan modul elektronik terhadap keterampilan proses siswa kelas X SMAN 2 Tidore kepulauan pada materi stokiometri; dan (2) nilai gain $85 \%$ menunjukkan interpretasi tinggi terhadap peningkatan keterampilan proses siswa setelah penggunaan video praktikum dengan modul elektronik.

\section{DAFTAR PUSTAKA}

Agustina, A., \& Novita, D. (2012). Pengembangan Media Pembelajaran Video Untuk Melatih Kemampuan Memecahkan Masalah Pada Materi Larutan Asam Basa. Unesa Journal of Chemical Educatio, 1(1):10-16

Baeti, S.N., Binadja,A., \& Susilaningsih, E. (2014). Pembelajaran Berbasis Praktikum Bervisi Sets Untuk Meningkatkan Keterampilan Laboratorium Dan Penguasaan Kompetensi. Jurnal Inovasi Pendidikan Kimia, 8(1):1260-1270.

Erniwati., Eso, R., \& Rahmia, S. (2014). Penggunaan Media Praktikum Berbasis Video Dalam Pembelajaran Ipa-Fisika
Untuk Meningkatkan Hasil Belajar Siswa Pada Materi Pokok Suhu Dan Perubahannya. Jurnal Sains dan Pendidikan Fisika, 10(3):269-273.

Oktiarmi, P., Rusdi, M., \& Asrial. (2014). Pengembangan Bahan Ajar Multimedia Interaktif pada Praktikum Titrasi Asam Basa. Jurnal Edu-Sains, 3 (1):6-12.

Priyatno. 2009. Lima jam belajar olah data dengan SPSS. Penerbit Abdi: Yogyakarta.

Rosmalinda, D., Rusdi, M., \& Hariyadi, B., (2013). Pengembangan Modul Praktikum Kimia SMA Berbasis PBL (Problem Based Learning. Jurnal Edu-Sains, 2(2):1-7.

Sugiyono, (2008). Metode Penelitian Pendidikan Pendekatan Kuantitatif, Kualitatif, dan R\&D. Bandung: Alfabeta.

Trianto. (2007). Model Pembelajaran Dalam Terpadu Teori Dan Praktek. Jakarta: Prestasi Pustaka publisher.

Wijayanto \& Zuhri, M.S. (2014). Pengembangann E-Modul Berbasis Flip Book Maker Dengan Model Project Based Learning Untuk Mengembangkan Kemampuan Pemecahan Masalah Matematika. Prosiding Mathematic and Sciences Forum.12:625-628.

Zulvianda, H., Hanum, L., \& Nazar, M. (2016). Pengembangan E-Module Kimia SMA Pada Materi Larutan Elektrolit dan Non Elektrolit. Jurnal Ilmiah Mahasiswa Pendidikan Kimia, 1(3):9-16. 